\title{
Factor Analysis and Profit Achievement For Trading Company by Using Rough set Method
}

\author{
M.Ardiansyah Sembiring*1), Zulfi Azhar ${ }^{2)}$ \\ Departement Informsation System, STMIK Royal Kisaran \\ Jl. Prof. M. Yamin 173 Kisaran, Sumatera Utara 21222 Telp: (0623) 41079 \\ ${ }^{* 1)}$ E-mail : adinmantap88@gmail.com ${ }^{2}$ E-mail : zulfi_azhar@yahoo.co.id
}

Article history:

Received :16/05/2017

Revised 30/06/2017

Accepted 05/06/2017

Keywords:

Data Mining,

General Rules,

Profit,.

Rough Set DSS

This research has been done to analysis the financial raport fortrading company and it is intimately related to some factors which determine the profit of company. The result of this reseach is showed about New Knowledge and perform of the rule. In discussion, by followed data mining process and using Rough Set method. Rough Set is to analyzed the performance of the result. This reseach will be assist to the manager of company with draw the intactandobjective. Rough set method is also to difined the rule of discovery process and started the formation about Decision System, Equivalence Class, Discernibility Matrix, Discernibility Matrix Modulo D, Reduction and General Rules. Rough set method is efective model about the performing analysis in the company..

Copyright $\odot 2017$ International Journal of Artificial Intelegence Research. All rights reserved.

\section{INTRODUCTION}

Profit is the goal for a trading company. But the other side, the tight level of competition in the business world and it is refered that the company can be continued to evaluate themselves, many techniques have been applied to a variety of domains in business and, including performaning, finance especially for employee. One way, the objective is to drawn the condition and evalution of the company. Some result obtained were calculated the profit every month. and the result will be analayzed the profit based on variabels and arranged it as the target one period. It is calculated to get some variables the seller - buyer about the stock of goods and the only thing matter is the chronology of work. Every last month in christ. Many effected of variables about the loss - profit every period, therefore the best way is analyzed to get information with correct and deeply. But also the information will be received as the progress for taking decision.

The reseacher has been done for a trading company of CV Budi Jaya. The company is sold the packaging food

Discovery includes predection, through which the analysis finds patterns to help the problem about factor analysis and effect of profit achievment. Following these two goals the reseacher has been applied to effect the progress of profit. The factor is refered about material of evaluation but the instact is not presented., because it is only showed about to the seller. The company will be obtained through big seller. An important issue in this company can be increased the profit but it is not focused or maximal as the effect of lost in this company.

In the following section, the reseacher will be focused to explain by using Rough Set method . this method are described here to show the diversity of the problems that Rough Set can handle. The data sets applied to Rosetta version 1.4.41. the reseacher will be 
compared and arranged the financial raport from the data of the company financial. This Rough Set method has been used Rodríguez (2013). This aim of study is to learn the situation about Current state of the art of algorithms this condition made therough set well suited for this method as the efective way to the Solar photovoltaic and isolation of Solar photovoltaic. the Rough sets for the identification and significant variables in the production of photovoltaic energy with through isolation system[1].

The most important problems that can be solved by Rough Set method so this study found that the variables rule to arranged profit and lost as the process of data mining method then rough followed by tools Rosetta version 1.4.41 for including new knowledge.

Limitation in which the methods are divided into three types:

1. Implementation is used rought set method to analayze the calculation of distributor company in Our Business of CV Budi Jaya

2. Found the rule of variables and arranged the profit/lost with suitable about the data mining process and rough set method.

3. Testing about the decision system use dextraction process by Tools Rosetta versi 1.4.41.

\section{LITERATURE REVIEW}

According to the standart of financial accounting No. 25 (IAI, 2007), said that the profit as the main report to show the performance of a company during a certain period. Information about the company's performance, especially for making decisions about the economic resources and a company will be managed to the future[2].

Data mining algorithm based on rough set method discussed, which is used to extract decision-making rule from data set. The basic concepts of rough set method are introduced and used in the algorithm. An example that uses the algorithm to acquire designing rule from the knowledge Database. It is related about Knowledge Discovery in Database (KDD) which is refered to the broad process of finding knowledge in data, and emphasizes the "high-level" application of particular data mining methods, or this application of algorithms for extracting patterns from data without the additional steps of the KDD [3].

In here there are divided of process of finding knowledge in data [4] :

1. Data Selectionis defined as the process of determining the appropriate data type and source, as well as suitable instruments to collect data. Data selection precedes the actual information of Knowledge Discovery in Database.

2. Preprocessing :The data we have collected are not clean and may contain errors, missing values, noisy or inconsistent data. Therefore we need to apply different techniques to get rid of such anomalies. And other information can be relevant about Knowledge Discovery in Database or external data.

3. Transformation : The data even after cleaning are not ready for mining as we need to transform them into forms appropriate for mining. The techniques used to accomplish this are smoothing, aggregation, normalization etc. Coding process as the perform of Knowledge Discovery in Database

4. Data mining: is to applied data mining techniques on the data to discover the interesting patterns. The techniques like clustering and association analysis are among the many different techniques used for data mining.

5. Interpretation / Evaluation : This step involved visualization, transformation, removing redundant patterns etc from the patterns and the product of information is showed about data mining.

Data mining has emerged as a discipline that contributes tools for data analysis, discovery of new knowledge, and autonomous decision making. In here, the basic concepts of rough set theory and other aspects of data mining are introduced. The rough set theory offers a viable approach for extraction of decision rules from data sets. [5]. We can drwan the picture in bellow it 


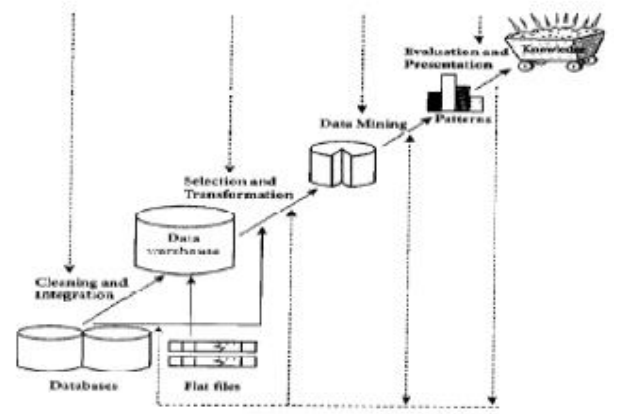

Fig. 1. The Steps of the KDD Process

Data mining is also the computing process of discovering patterns in large data sets involving methods at the intersection of artificial intelligence, machine learning, knowlege [6]. The Rough Set method rough set, first described by Polish computer scientist Zdzisław Pawlak. In terms of a pair of sets which give the lower and the upper approximation of the original set. As the tool of match to handle uncertain or less common [7].Rough set theory is one of many methods that can be employed to analyse uncertain (including vague) systems, although less common than more traditional methods of probability, statistics, [8] . In the Rough Sets Theory, information systems are used to represent knowledge. The notion of an information [9]:

1. Formed the Informasi System.tabel

2. Formed Decision System tabel as the basic former of Equivalen Class.

3. Formed the Equivalen Class.

4. The process of Discernibility Matrix or Discernibility Matrix Modulo D

5. Process "Reduction"

6. Input the Conclusion and obtained the final result through General Rules process

The steps of rough set method with draw in the following way:



Fig. 2 Process of Rough Set Method

\section{a. Information System}

In roughset, can be defined a data set and then A data set is represented as a table; every column represents an attribute that can be measured for each objects.." This table is called an information table:

$$
\mathrm{IS}=\{\mathrm{U}, \mathrm{A}\}
$$

Where $\mathrm{U}$ is a finite sets of objectives (universe), and A setter is not empaty of attribute:

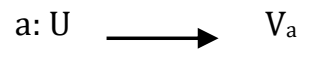

For each $a \in A$. Set $V a$ is a value set of a. $U=\left\{\mathrm{e}_{1}, \mathrm{e}_{2}, \ldots, \mathrm{e}_{\mathrm{m}}\right\}$ is domain of the example collection and $A=\left\{a_{1}, a_{2}, . ., a_{n}\right\}$ is called of attribute about Conditions with sequence.

b. Decission System

In using the information system, found that the outcome The concept of decisionmaking is to primarily allow the user needed information to make particular decisions. The Decision system can be drawn as follows:(3)

$$
\mathrm{IS}=(\mathrm{U},\{\mathrm{A}, \mathrm{C}\})
$$


where :

$\mathrm{U}=\{\mathrm{x} 1, \mathrm{x} 2, \ldots, \mathrm{xm}\} \mathrm{y}$ is domain of the example.collection

$\mathrm{A}=\{\mathrm{a}, \mathrm{a} 2, \ldots$, an $\}$ is value of attribute collection with sequence or attribute.

$\mathrm{C}=$ Decision attributes.

\section{c. Equivalence Class}

Equivalence class is collected with familiar the objects and signed attribute in $A \in(U$, A).

\section{d. Discernibility Matrix}

Definition of Discerniblity Matrix: is given IS $\mathrm{A}=(\mathrm{U}, \mathrm{A})$ and $\mathrm{B} \subseteq \mathrm{A}$, discernibility matrix from $A$ to $M B$, where the entry $M B(I, j)$ consists of attribute collection which is different between object $X_{i}$ and $X_{j}$.

\section{e. Discernibility Matrix Modulo D}

Definition of Discernibility Matrix Modulo or called $\mathrm{MB}(\mathrm{I}, \mathrm{j})$ is refered to attribute collection and different between object Xi and $\mathrm{Xj}$. where found that the different about attribute and decisions, it is as follows: DS $A=(U, A\{d\{)$ is subset of set of all attributes $B$ $\subseteq \mathrm{A}$, Discernibility Matrix Modulo D set of ordered A, MBd.

\section{f. Reduct}

Reduct is the selection of maximal attribute(interesting attribute).This provides a logic foundation for the study of reducts. On this basis, the researcher studied reduction construction by using Prime Implicant and determine sets of reduct.

\section{g. Gerated Rules}

The next process is refered to the overall process of discovering useful knowledge from database through It involved the extraction rules of the decision system.

\section{SYSTEM ANALYSIS}

Decission system will be followed the process of system as follows:
Table 1 Sample of Decission System

\begin{tabular}{|c|c|c|c|c|}
\hline SALE & $\begin{array}{c}\text { PURCHA } \\
\text { SE }\end{array}$ & $\begin{array}{c}\text { STOCK } \\
\text { WAREHOU } \\
\text { SE } \\
\end{array}$ & $\begin{array}{c}\text { OPERATIN } \\
\text { G } \\
\text { EXPENSES } \\
\end{array}$ & PROFIT \\
\hline $\begin{array}{c}\text { LOW } \\
\text { TARGET }\end{array}$ & SMALL & SMALL & $\begin{array}{c}\text { NO } \\
\text { EFISIEN }\end{array}$ & FAILED \\
\hline $\begin{array}{c}\text { LOW } \\
\text { TARGET }\end{array}$ & BIG & FULL & $\begin{array}{l}\text { NO } \\
\text { EFISIEN }\end{array}$ & FAILED \\
\hline $\begin{array}{c}\text { LOW } \\
\text { TARGET }\end{array}$ & SMALL & SMALL & $\begin{array}{l}\text { NO } \\
\text { EFISIEN }\end{array}$ & FAILED \\
\hline $\begin{array}{c}\text { GOOD } \\
\text { TARGET }\end{array}$ & BIG & FULL & $\begin{array}{c}\text { NO } \\
\text { EFISIEN }\end{array}$ & FAILED \\
\hline $\begin{array}{c}\text { UNDER } \\
\text { TARGET } \\
\end{array}$ & BIG & FULL & $\begin{array}{c}\text { NO } \\
\text { EFISIEN }\end{array}$ & FAILED \\
\hline $\begin{array}{c}\text { HIGH } \\
\text { TARGET }\end{array}$ & BIG & FULL & EFISIEN & $\begin{array}{c}\text { REACHE } \\
\text { D }\end{array}$ \\
\hline $\begin{array}{l}\text { OPTIMIZATI } \\
\text { ON TARGET }\end{array}$ & BIG & FULL & EFISIEN & $\begin{array}{c}\text { REACHE } \\
\mathrm{D}\end{array}$ \\
\hline ......... & ......... & ......... & ......... & ......... \\
\hline $\begin{array}{c}\text { OPTIMZATIO } \\
\text { N TARGET }\end{array}$ & BIG & FULL & EFISIEN & $\begin{array}{c}\text { REACHE } \\
\text { D } \\
\end{array}$ \\
\hline
\end{tabular}

Table 1 shown the Decision Systems in this reseach. It is related n object, E1, E2, E3, $\mathrm{E} 4, \ldots \ldots . . \mathrm{E} 48$ and condition attributeas the sale, purchase, Warehouse stock, and operating expense while the profit is showed the decision attribute.

Decission System from Rosetta which has been imported into the system through Data input procedure. The procedure is illustrated in this Figure 3.

\begin{tabular}{|c|c|c|c|c|c|c|}
\hline \multicolumn{5}{|c|}{ II Sheet1S } & \multicolumn{2}{|c|}{ 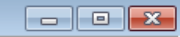 } \\
\hline & PENJUALAN & PEMBELIAN & $\begin{array}{c}\text { STOK } \\
\text { GUDANG }\end{array}$ & $\begin{array}{l}\text { BEBAN } \\
\text { USAHA }\end{array}$ & PROFIT & A \\
\hline 1 & DIBAWAH & KURANG & SEDIKI & TIDAK EFISIE & TIDAK TERC & \\
\hline 2 & DIBAWAH & BANYAK & PENUH & TIDAK EFISIE & TIDAK TERC & \\
\hline 3 & DIBAWAH & KURANG & SEDIKT & TIDAK EFISIE & TIDAK TERC & \\
\hline 4 & TARGET & BANYAK & PENUH & EFISIEN & TERCAPAI & \\
\hline 5 & TARGET & BANYAK & PENUH & EFISIEN & TERCAPAI & $\equiv$ \\
\hline 6 & TARGET & BANYAK & PENUH & EFISIEN & TERCAPAI & \\
\hline 7 & TARGET & BANYAK & PENUH & TIDAK EFISIE & TIDAK TERC & \\
\hline 8 & DIBAWAH & BANYAK & PENUH & TIDAK EFISIE & TIDAK TERC & \\
\hline 9 & DIATAS & BANYAK & PENUH & EFISIEN & TERCAPAI & \\
\hline 10 & TARGET & BANYAK & PENUH & EFISIEN & TERCAPAI & \\
\hline 11 & TARGET & BANYAK & PENUH & EFISIEN & TERCAPAI & \\
\hline 12 & TARGET & KURANG & SEDIKT & TIDAK EFISIE & TERCAPAI & \\
\hline 13 & DIATAS & BANYAK & PENUH & EFISIEN & TERCAPAI & \\
\hline 14 & DIBAWAH & KURANG & SEDIKT & TIDAK EFISIE & TIDAK TERC & \\
\hline 15 & TARGET & BANYAK & PENUH & TIDAK EFISIE & TIDAK TERC & \\
\hline 16 & TARGET & BANYAK & PENUH & EFISIEN & TERCAPAI & \\
\hline \begin{tabular}{|l|l}
17 \\
\end{tabular} & DIATAS & BANYAK & PENUH & EFISIEN & TERCAPAI & \\
\hline 18 & DIATAS & KURANG & SEDIKT & TIDAK EFISIE & TERCAPAI & \\
\hline 19 & DIBAWAH & KURANG & PENUH & EFISIEN & TERCAPAI & \\
\hline 20 & TARGET & BANYAK & PENUH & EFISIEN & TERCAPAI & \\
\hline 21 & TARGET & BANYAK & PENUH & EFISIEN & TERCAPAI & \\
\hline 22 & DIATAS & KURANG & SEDIKT & TIDAK EFISIE & TERCAPAI & \\
\hline 23 & TARGET & BANYAK & PENUH & EFISIEN & TERCAPAI & \\
\hline 24 & DIATAS & BANYAK & PENUH & EFISIEN & TERCAPAI & - \\
\hline
\end{tabular}

Fig. 3 Decission System of Rosetta

The next step of Rosetta tools will be done Equivalence Class process and Dicernibility Matrix Modulo D, but it was not direcly displayed. But the result of Equivalence Class table and Dicernibility Matrix Modulo D with direcly the process and 
the Rough Set method reduct. Result of reduct is shown in this Figure 4.

\begin{tabular}{|c|c|c|c|}
\hline \multicolumn{2}{|c|}{ I. No name } & \multicolumn{2}{|c|}{$\square$ 回 $x$} \\
\hline & Reduct & Support & Length \\
\hline 1 & $\{$ BEBAN USAHA $\}$ & 60 & 1 \\
\hline 2 & $\{$ PENJUALAN\} & 60 & 1 \\
\hline 3 & \{PENJUALAN, STOK GUDANG\} & 59 & 2 \\
\hline 4 & $\{$ PENJUALAN, BEBAN USAHA\} & 58 & 2 \\
\hline 5 & $\{$ PEMBELIAN, BEBAN USAHA\} & 60 & 2 \\
\hline 6 & \{STOK GUDANG, BEBAN USAHA\} & 60 & 2 \\
\hline 7 & \{PENJUALAN, PEMBELLAN\} & 59 & 2 \\
\hline 8 & \{PEMBELLAN, STOK GUDANG\} & 57 & 2 \\
\hline
\end{tabular}

Fig. 4 Result of Reduct Rosetta

Figure 4 shown the results of the reduct process and performed with the result of a minimum attribute about 8 (eight) in pairs. then this attribute- will be showed in this attribute to do the general rule. Result of the general rule is shown through Rosetta process in this Figure 5.

\begin{tabular}{|c|c|}
\hline \multicolumn{2}{|c|}{ D. General Rules } \\
\hline & Rule \\
\hline 1 & BEBAN USAHA(EFISEN) $\Rightarrow$ PROFT(TERCAPAI) \\
\hline 2 & PENUUALAN(DATAS) $\Rightarrow$ PROFT(TERCAPAI) \\
\hline 3 & PENUUALAN(DBAWAH) $\Rightarrow$ PROFT(TIDAK TERCAPAI) OR PROFT(TERCAPAI) \\
\hline 4 & PENUUALAN(DBAWAH) AND STOK GUDANG(SEDKKT) => PROFT(TDAK TERCAPAI) \\
\hline 5 & PENUUALAN(TARGET) AND STOK GUDANG(SEDIKT) => PROFT(TERCAPAI) \\
\hline 6 & PENUUALAN(DBAANAH) AND STOK GUDANG(PENUH) $\Rightarrow$ PROFT(TDAK TERCAPAl) OR PROFT(TERCAPAl) \\
\hline 7 & PENUALLAN(DBAANAH) AND BEBAN USAHA(TIDAK EFISEN) $\Rightarrow$ PROFT(TDAK TERCAPAI) \\
\hline 8 & PENUUALAN(TARGET) AND BEBAN USAHA(TDAK EFISEN) $\Rightarrow$ > PROFT(TDAK TERCAPAI) OR PROFT(TERCAPAI) \\
\hline 9 & PEMBELLAN(BANYAK) AND BEBAN USAHA(TDAK EFISEN) $\Rightarrow$ > PROFT(TDAK TERCAPAI) \\
\hline 10 & STOK GUDANG(PENUH) AND BEBAN USAHA(TIDAK EFISEN) $\Rightarrow$ PROFT(TDAK TERCAPAI) \\
\hline 11 & PENNUALAN(TARGET) AND PEMBELLAN(KURANG) => PROFT(TERCAPAI) \\
\hline 12 & PENJUALAN(DBBAWAH) AND PEMBELLAN(BANYAK) $\Rightarrow$ PROFT(TIDAK TERCAPAI) \\
\hline 13 & PEMBELLAN(KURANG) AND STOK GUDANG(PENUH) $\Rightarrow$ PROFT(TERCAPAI) \\
\hline 1 & III \\
\hline
\end{tabular}

Fig. 5 Result of General Rule Rosetta

After finished the process . we can input, they were : Decision System, Equivelence Class, Discernibility Matrix Modulo D, Reduction until we found that the former new knowledge, we found that the output as the result of Generated Rules. We can see Figure. 5 there were rule of this derection as the target for including the profit/loss in the following way:

1. If operating expense $=$ Efficient Then Profit $=$ Reached
2. If Sale $=$ Over Then Profit $=$ Reached

3. If Purchase $=$ Under Then Profit $=$ Failed or Profit $=$ Reached

4. If Purchase= Under and Warehouse stock $=$ Small Then Profit $=$ Failed

5. If purchase $=$ Target and Warehouse stock $=$ Small Then Profit $=$ Reached

6. If purchase $=$ Under and Warehouse stock Full=Then Profit $=$ Reached Or Profit $=$ Failed

7. If purchase $=$ Under and operating expense $=$ No Efficient Then Profit $=$ Failed

8. If purchase $=$ Target and operating expense $=$ No Efficient Then Profit $=$ Failed or Profit $=$ Reached

9. If purchase $=\mathrm{Big}$ and operating expense $=$ No Efficient Then Profit $=$ No Efficient

10. If Warehouse stock $=$ Full and operating expense $=$ No Efficient Then Profit $=$ Failed

11. If Sale $=$ Target and Sale $=$ Small Then Profit $=$ Reached

12. If Purchase $=$ Under and Purchase $=$ Big Then Profit $=$ Failed

13. If Purchase $=$ Small and Warehouse stock $=$ Full Then Profit $=$ Reached

Based on the result of generated rule were 13 (thirteen) rules or new knowledge composed of the attributes. After that the reseacher has been done to analysis the rule of Sales Attribute about 9 times and Attribute of operating expense were 5 times, Purchase Attribute were 4 times, and stock Warehouse were 5 times. So we can be seen that the attribute to define the achievement of profit from the calculation of profit/loss and appeared the sale attribute because the attribute got the highest number. after Sale, The next attribute got the high numbers are Operating Expenses and Warehouse Stock. They got the same of numbers and also appeared as the second occurrence. Then the last attribute got the smallest number is Purchase.

\section{SYSTEM EVALUATION}

At the beginning of the study, the reseacherhas explained the problems to analysis about profit / loss with objective. And to define the target of profit in the 
company. In here, this description about traditional system and new system.

\section{a. Traditional System}

Traditional system is to difined the variable which the profit can be included yes or no, it is showed about variable to ignore other variables, but also effected to the profit. Then the impact will be happened to conduce the evaluation of the company performance especially for our company of CV Budi Jaya because it was non-compliance in our company and then appread the loss.

\section{b. New System}

Some the right way to do the new system. The data mining by used rough set method to solve the problems and Rosetta 1.4.41 (testing tool) as the result about parameters and got target the profit to a new knowledge as follows:

\section{Information Searching}

In this process, the information searching used tools Rosetta 1.4.41 because it was efectively and easy and assisted through the process in the rough set method from decission system data about profit/loss as efective way to the attribute and known every period for accounting. Then we found the right result when we used by manually and we will be Spared the human error.

\section{GeneratingKnowledge}

We used this tools Rosetta 1.4.41, Knowledgewe can seen with perfectly, clear, good parameters or we called that Reductand got the General Rules. This reseach will be detailed.

\section{CONCLUSION}

Based on result the chapter I to chapter IV the reseacher has been done to take the conclution which is used for reader or many reseachers. In other side this reseach can be usefull for us. Therefore, a conclusion in this study are:

1. Implementation of the rough set method can be answered the problems to analyze the result of profit/loss and finding the rule about profit as the target for accounting period.

2. Based on the rule found that the attribute this conditions can be effected to get profit based on result of profit / loss and calculation the seller, because the seller of attribute is obtained the common attribute. All attributes found the result of rule. This conditions for next picture will be affected after Sale the Business Expenses. then Operating Expenses of attribute can be effected about sale and Stock Warehouse.

3. Testing about the decision system used extraction process by Tools Rosetta versi 1.4.41. it's easy the common of company to got new knowledge and taking decision

\section{REFERENCES}

[1] Rodriguez, A.P.R danRiverola, F.F. "Applying Rough Set for the Identification of Significant Variables in Photovoltaic Energy Production with Isolated System", JurnalTeknologi, 2013, ISSN:0127-9696, pp 9-16.

[2] Meythi dan Selvy Hartono, "Pengaruh Informasi Laba dan Arus Kas Terhadap Harga Saham".JurnalAkuntansi, 2012, ISSN:20864159, pp. 57- 59.

[3] Subekti Mujiasih.'Pemanfaatan Data Mining untuk Prakiraan Cuaca".2012 Volume 12, pp. $189-195$.

[4] Riani Lubis dan Angga Ginanjar Mabrur, "Penerapan Data Mining untuk Memprediksi Kriteria Nasabah Kredit", Jurnal Komputa, 2012. Volume 1, pp. $53-57$.

[5] Eko Prasetyo, " Data Mining Konsep dan Aplikasi Menggunakan Matlab", Ed.I, Yogyakarta : 2012, Andi, pp. 3-7.

[6] Fajar Astuti Hermawati “Data Mining”, Edisi I, Yogyakarta : 2009, Andi, pp.2-3.

[7] Obadi Gamila, "A Tolerance Rough Set Based Overlapping Clustering for the DBLP Data".Computer Society IEE, 2010, pp.57 59.

[8] Gogoi Prasanta," Efficient Rule Set Generation Using Rough Set Theory for Classification of High Dimensional Data", IJSSAN, ISSN: 2248-9738 Volume 1, 2011, Hlm. $13-60$. 